\title{
Torneträsk tree-ring width and density AD 500-2004: a test of climatic sensitivity and a new 1500-year reconstruction of north Fennoscandian summers
}

\author{
Håkan Grudd
}

Received: 28 June 2007 / Accepted: 15 December 2007/Published online: 30 January 2008

(C) The Author(s) 2008

\begin{abstract}
This paper presents updated tree-ring width (TRW) and maximum density (MXD) from Torneträsk in northern Sweden, now covering the period AD 500-2004. By including data from relatively young trees for the most recent period, a previously noted decline in recent MXD is eliminated. Non-climatological growth trends in the data are removed using Regional Curve Standardization (RCS), thus producing TRW and MXD chronologies with preserved lowfrequency variability. The chronologies are calibrated using local and regional instrumental climate records. A bootstrapped response function analysis using regional climate data shows that tree growth is forced by April-August temperatures and that the regression weights for MXD are much stronger than for TRW. The robustness of the reconstruction equation is verified by independent temperature data and shows that $63-64 \%$ of the instrumental inter-annual variation is captured by the tree-ring data. This is a significant improvement compared to previously published reconstructions based on tree-ring data from Torneträsk. A divergence phenomenon around $\mathrm{AD} 1800$, expressed as an increase in TRW that is not paralleled by temperature and MXD, is most likely an effect of major changes in the density of the pine population at this northern tree-line site. The bias introduced by this TRW phenomenon is assessed by producing a summer temperature reconstruction based on MXD exclusively. The new data show generally higher temperature estimates than previous reconstructions based on Torneträsk tree-ring data. The late-twentieth century, however, is not exceptionally warm in the new record: On decadal-to-centennial timescales, periods around $\mathrm{AD} 750$,
\end{abstract}

H. Grudd ( $\square)$

Department of Physical Geography and Quaternary Geology,

Stockholm University, 10691 Stockholm, Sweden

e-mail: hakan.grudd@natgeo.su.se
1000,1400 , and 1750 were equally warm, or warmer. The 200-year long warm period centered on AD 1000 was significantly warmer than the late-twentieth century $(p<0.05)$ and is supported by other local and regional paleoclimate data. The new tree-ring evidence from Torneträsk suggests that this "Medieval Warm Period" in northern Fennoscandia was much warmer than previously recognized.

\section{Introduction}

The extensive compilation of Scots pine (Pinus sylvestris L.) tree-ring data in the Torneträsk area of northern Sweden has resulted in one of the longest continuous tree-ring width (TRW) chronologies in the world, covering the period 5407 BC to AD 1997 (Bartholin 1987; Briffa et al. 1990; Grudd et al. 2002). This 7,400-year precisely dated record was amalgamated from 880 individual tree samples, collected from living trees and remnant (subfossil) wood preserved on dry ground and in small lakes. From this material, Schweingruber et al. (1988) used a selection of 65 samples to produce a record of maximum density (MXD), covering the period AD 441-1980. This 1,540-year density record is, to date, the longest in the world.

Tree growth in the north of Fennoscandia has a strong correlation to summer temperature: TRW is predominantly correlated with a short peak period of summer warmth (Lindholm and Eronen 1995; Kirshhefer 2001; Grudd et al. 2002) while MXD is related to a longer summer period and the correlation is usually much higher (Briffa et al. 1990; McCarroll et al. 2003). Thus, MXD is the more powerful proxy for summer temperature and, as a result, multi proxy temperature reconstructions based on these two tree-ring variables will be greatly dominated by MXD (Briffa et al. 2002a). 
Torneträsk tree growth is representative of a wide area in northern Fennoscandia (Briffa et al. 1992; Gouirand et al. 2007) and the tree-ring data have been used in a number of high resolution large-scale climate reconstructions (Jones et al. 1998; D’Arrigo et al. 1999; Mann et al. 1999; Briffa 2000; Briffa et al. 2002b; Esper et al. 2002; Mann and Jones 2003; Luterbacher et al. 2004; Moberg et al. 2005) with the objective to place the documented late-twentieth century temperature increase (IPCC 2007) in a longer time-scale perspective. The amplitude of this recent temperature change is, however, debated in context of the last millennium (Jones et al. 2001; Mann et al. 2002; Cook et al. 2004; Luterbacher et al. 2004; Esper et al. 2005; Moberg et al. 2005; D’Arrigo et al. 2006) and it is also recognized that existing millennialong climate reconstructions rely on proxy data that may underestimate climatic variability (Briffa and Osborn 2002; Osborn and Briffa 2004; von Storch et al. 2004). A majority of the proxy reconstructions carry a strong weight from treering data. However, they are also seriously hampered by the lack of data in the most recent period (Briffa et al. 2004; Esper et al. 2005; D’Arrigo et al. 2006). The problem can be illustrated by the Torneträsk MXD data which terminate in AD 1980, i.e. prior to the "extreme" temperature increase in the most recent decades. Thus, there is an urgent need to update existing tree-ring collections throughout the northern hemisphere and to further develop networks of high-resolution proxy data that can capture the magnitude and rate of temperature change over the last millennium.

Our ability to place the recent temperature increase in a longer paleoclimate perspective is also hampered by an apparent change in the sensitivity of recent tree-growth to temperature at high northern latitudes where trends in TRW and MXD have been reported to increasingly diverge from the instrumental records during the second half of the twentieth century (Jacoby and D'Arrigo 1995; Briffa et al. 1998a, b; D'Arrigo et al. 2007). The diverging trends are not consistent throughout the widely-distributed circumpolar sites (Briffa et al. 2004; Driscoll et al. 2005; Wilmking et al. 2005; D'Arrigo et al. 2006) and the mechanisms behind this phenomenon are poorly understood.

This paper presents new tree-ring data from Torneträsk which update the existing records to AD 2004. The sensitivity of recent tree growth to temperature is examined and a new summer temperature reconstruction is presented for the last 1,500 years in northern Fennoscandia.

\section{Materials, methods and results}

\subsection{The tree-ring data}

The tree-ring widths (TRW) and maximum densities (MXD) used in this study originates from the Lake
Torneträsk area, northern Sweden (68.21-68.31 ${ }^{\circ} \mathrm{N}, 19.45-$ $19.80^{\circ} \mathrm{E}$, and $350-450 \mathrm{~m}$ a.s.1.). The sample material is derived from living and subfossil Scots pine (Pinus sylvestris L.). The subfossil samples come from two sources: Dead wood found on dry ground, and submerged logs retrieved from small mountain lakes. All material is regarded as samples from the same population. A summary and temporal distribution of some raw data statistics are given in Table 1 and Fig. 1.

MXD data from Torneträsk were first published by Schweingruber et al. (1988). This original data set of 65 individual tree-series covered the time period AD 441-1980 and is hereafter denoted SEAL80 [WSL (Dendro Database, WSL, Switzerland. http://www.wsl.ch/dendro/dendrodb. html). Here, the MXD data is updated to AD 2004 using new samples from 35 relatively young trees. Thus, the new Torneträsk MXD data-base includes samples from a total of 100 trees and covers the period AD 441-2004. Dry dead wood covers the period AD 441-1789 and living trees cover the period AD 1336-2004. No subfossil lake material is included in the MXD data. In SEAL80, data for the most recent period originated entirely from old-aged trees and, as a result, tree rings from the twentieth century had a much higher average cambial age than the earlier part of the record. The new data have significantly reduced the average cambial age of the tree-ring data in the twentieth century (Fig. 1a).

The TRW data are part of a much larger data set than the one used for MXD (Grudd et al. 2002). The TRW data are updated to $\mathrm{AD} 2004$ using the same 35 trees as for MXD and a total of 620 trees is now used to cover the period $\mathrm{AD}$ 500-2004 (Fig. 1b). The sources of these data are living trees, dead dry wood and subfossil logs that were recovered from small lakes.

\subsection{X-ray densitometry}

The new data were produced using an Itrax WoodScanner from Cox Analytical Systems (http://www.coxsys.se), while the original SEAL80 data were produced using the DENDRO2003 X-ray instrumentation from Walesch Electronic (http://www.walesch.ch). Both systems produce

Table 1 Raw tree-ring data statistics

\begin{tabular}{llll}
\hline & TRW & MXD & SEAL80 \\
\hline Number of samples & 620 & 100 & 65 \\
Arithmetic mean & 0.796 & 0.615 & 0.611 \\
Standard deviation & 0.329 & 0.079 & 0.061 \\
Median segment length & 174 & 216 & 276 \\
Mean series inter-correlation & 0.336 & 0.419 & 0.382 \\
\hline
\end{tabular}




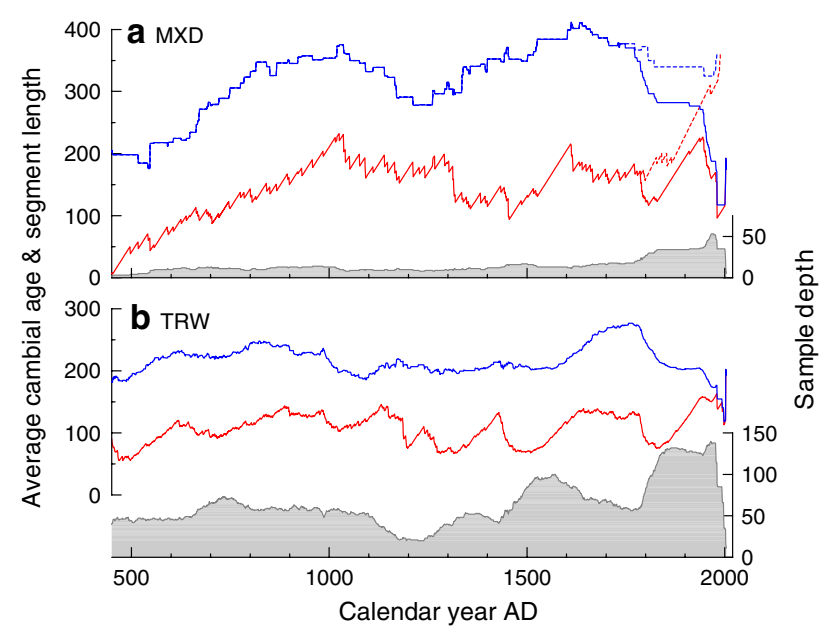

Fig. 1 The updated Torneträsk tree-ring data for the last 1,500 years now constitutes a 100 series of MXD; and b 620 series of tree-ring width (TRW). The number of replicate series for each year (the sample depth) is shaded in grey, the average cambial age of the constituent tree rings for each year is illustrated by the red curves, and the average segment length by the blue curves. The hatched curves in a show cambial age and segment length for the previously existing MXD data (SEAL80)

high-resolution radiographic (X-ray) images from thin laths that are cut from the samples. Before X-raying, the laths are treated with alcohol in a Soxhlet apparatus to extract resins and other movable compounds in the wood that are not related to the annual production of wood tissue (Schweingruber et al. 1978).

In the DENDRO2003 system, laths are placed on an Xray film and exposed to X-rays (similar to the X-ray technique traditionally used in hospitals). Subsequently, light intensity (grey levels) in the film is analysed using a manually operated photo-sensor. The dimensions of the photo-sensor slit varies with the choice of magnifying lens, resulting in varying dimensions from $0.004 \times 1$ to $0.05 \times 5 \mathrm{~mm}$. Grey-level light intensity is calibrated to wood density using a standard calibration wedge which is $\mathrm{X}$-rayed at the same time as the sample laths.

In the Itrax WoodScanner system, the sample laths are scanned in increment steps using a focused high-energy X-ray beam and an X-ray line camera that detects the amount of radiation that passes through the sample. The output from this system is a digital image with 65,536 grey levels (16 bit) with a maximum resolution of $0.01 \mathrm{~mm}$ (2,540 dpi). Resolution is user defined by the choice of increment step-length during the scanning procedure. The digital image is subsequently analysed using the commercial software WinDendro (http://www.regentinstruments.com) where density, as represented by the grey levels, is determined by means of a "virtual" slit scanning process (Guay et al. 1992). The width of the virtual slit is always
1 pixel and length is user defined. Grey-level light intensity is calibrated to wood density using the same type of standard calibration wedge as used in the DENDRO2003 system.

Hence, MXD in the new data was measured using a method which is comparable to the method used for the SEAL80 data. The sensor-slit dimensions, however, differ slightly which means that there could, potentially, be a difference in the definition of MXD between the two data sets. The new data were analysed using a sensor width of $0.01 \mathrm{~mm}$ and a sensor length of 1.0-2.0 mm. The SEAL80 data were analysed using a sensor width of $0.03 \mathrm{~mm}$ and a sensor length of 0.08-1.0 mm (Schweingruber 1988; and personal communication, Daniel Nievergelt at the WSL Laboratory). The difference in sensor width (the direction of tree-ring growth) will have a greater effect than the difference in length because the variation in intra-ring density is largest in this direction. For small rings, therefore, a smaller sensor width should provide more accurate MXD values.

To assess the difference between the two techniques, one sample from the original SEAL80 data was re-measured in the Itrax WoodScanner. The calibration results (Fig. 2) show that the average MXD is virtually identical in the two measurement series and that there is no significant relation between the residuals and the ring widths. However, the variability around the mean is different: The new measurement series has a significantly higher standard deviation $(\mathrm{SD}=0.116)$ than the original measurement series $(\mathrm{SD}=0.082)$. As it was not possible to re-measure all 65 series in the original SEAL80 data, 15 measurement series from each of the two data sets, and from a common time period, were used to construct two raw data chronologies which were analysed for differences in mean and variance (Fig. 3). The mean MXD in these two chronologies are equivalent. The standard deviation around the mean, however, is higher in the new data, consistent with the calibration results.

The higher variability introduced by the new data for the most recent period of the record will have significant implications for the climate reconstruction and will lead to an under-estimation of the climatic variability in the earlier part of the record. The variance in each individual measurement series of the new data was therefore reduced by $29 \%$ in accordance with the calibration results (Fig. 2).

\subsection{Standardization}

The annual growth of a tree, manifest as TRW or MXD, may in theory be attributed to a restricted number of different growth-controlling factors (Cook 1990). At 

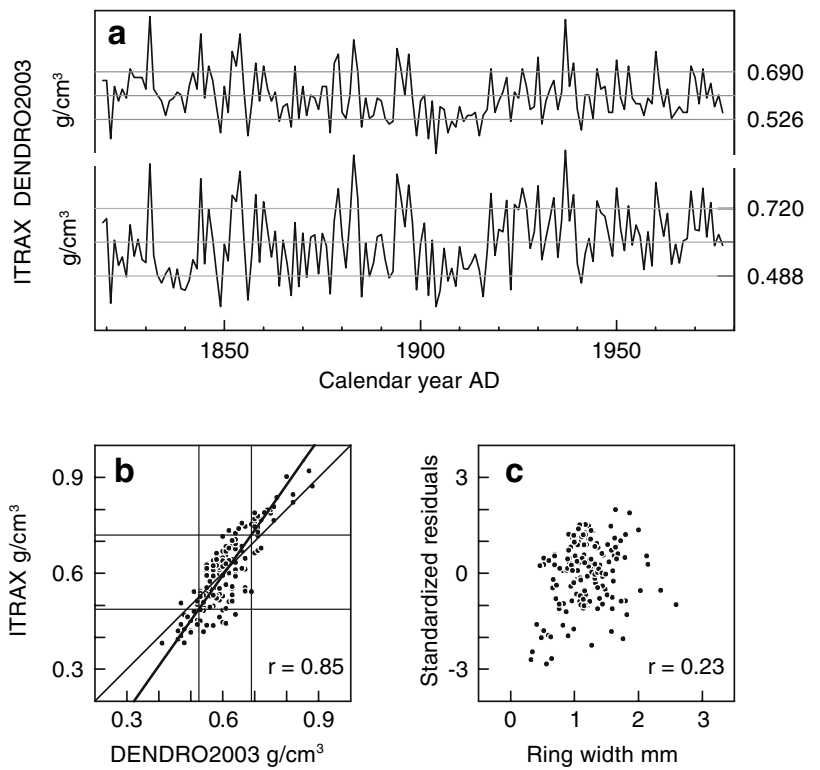

Fig. 2 Maximum density (MXD) as measured on the same sample, but using two different techniques: ITRAX and DENDRO2003. In a the standard deviation around the series mean is indicated by the horizontal lines. Panel $\mathbf{b}$ shows the correlation between the two measurement series, and c shows the relation between ITRAX residuals and ring width
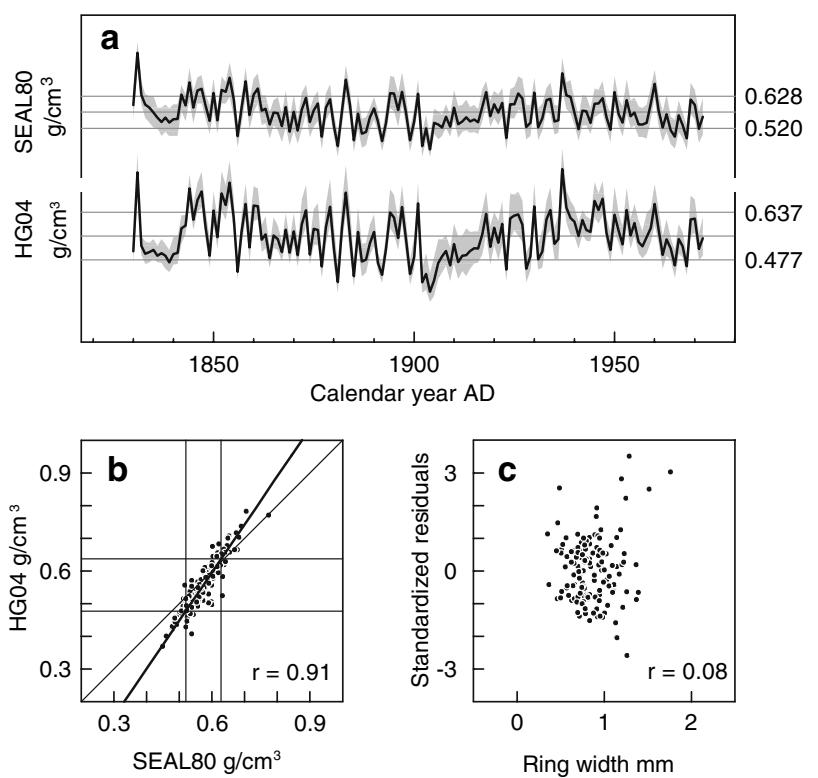

Fig. 3 A set of 15 trees from the original SEAL80 data (Schweingruber et al. 1988) and 15 trees from the new measurement data (here denoted HG04), from an overlapping time period, were averaged into raw data chronologies. a The shaded area represents the 95\% confidence intervals. The horizontal lines indicate the standard deviation around the series mean. Panel b shows the correlation between the chronologies, and $\mathbf{c}$ shows the relation between HG04 residuals and ring width

Torneträsk, trees live close to their climatological limit of distribution and, hence, annual production of wood tissue is primarily controlled by the climate (Tranquillini 1979). A secondary factor that controls the annual ring width and maximum density of an individual tree is related to the age/ size of the tree, and a third factor is the influence from nonclimatic changes in the surrounding physical and ecological environments (Fritts 1976; Schweingruber 1988). Using this basic concept, the observed time series of annual wood tissue production in a tree may be defined as the cumulative result of three separate factors: Climate $(C)$, tree age/size $(A)$, and the (non-climatic) environment $(\mathrm{E})$. Hence,

$G_{t}=C_{t}+A_{t}+E_{t}+\varepsilon_{t}$

where $G_{t}$ is the observed growth, measured as TRW or MXD at calendar year $t$, and $\varepsilon_{t}$ results from random (error) growth processes not accounted for by these other processes (Cook 1990).

Tree-ring chronologies are constructed by averaging replicate data for each individual calendar year. However, when used for paleoclimate reconstruction, the non-climatic information $\left(A_{t}\right.$ and $E_{t}$ in Eq. 1) first need to be removed from the individual raw data series $\left(G_{t}\right)$. This central concept in dendroclimatology is referred to as standardization (Fritts 1976; Cook et al. 1990) and the aim is to preserve as much of the climate-related information as possible while removing the un-wanted, nonclimatic information. Inevitably, however, a varying proportion of the low-frequency climatic information is also lost in this process. The choice of standardization method depends on the character of the tree-ring data but, in general, more complex statistical methods are needed when the non-climatic environmental factors have a strong impact on tree growth (Cook et al. 1990). In this study, tree growth is assumed to be forced by two dominant factors: The summer climate and the age/size of individual trees. This assumption is based on the strong connection to temperature for Torneträsk TRW and MXD data (Briffa et al. 1990; Grudd et al. 2002). Non-climatic environmental factors will certainly have been important for individual trees at different times, but these factors are regarded as haphazard events with random distribution over space and time and, hence, they can be regarded as part of the random error variable $\left(\varepsilon_{t}\right)$ in the conceptual linear aggregate equation (Eq. 1). An index $\left(I_{t}\right)$ of the climate signal can then be extracted by simply subtracting the age/size-related trend $\left(A_{t}\right)$ from the observed growth $\left(G_{t}\right)$.

For MXD, the index $\left(I_{t}\right)$ is calculated by subtraction. For TRW, however, the amplitude of variation will change over the lifetime of individual trees and the index is therefore calculated by division (Fritts 1976; Schweingruber 1988):

$I_{t}=\frac{G_{t}}{A_{t}}+\varepsilon_{t}$ 
This approach simultaneously removes the age/size-related trend and stabilizes the variance such that the mean and variance no longer systematically change with time.

The age/size-related trend $\left(A_{t}\right)$ is commonly modelled with a deterministic approach, i.e. by fitting a negative exponential function or linear trend to the data, or by using more flexible functions such as a smoothing spline (Fritts 1976; Cook and Kairiukstis 1990). These deterministic methods effectively preserve the high-frequency variation in the data while removing much of the slowly evolving changes such as biological growth trends. However, they also remove a major part of the long-term climatic trends. In this analysis, therefore, the data is standardized using an empirical method denoted Regional Curve Standardization (RCS) which has demonstrated a particular ability to preserve long-timescale climate variability in long tree-ring chronologies while removing most of the age related variance (Esper et al. 2003; D'Arrigo et al. 2006). The basic concept of the RCS method was used already by Stellan Erlandsson in his pioneer studies at Torneträsk (Erlandsson 1936) and the method was later employed and developed by Keith Briffa et al. (1992) using a much larger set of treering data from Torneträsk.

The RCS method has higher requirements on the data than other standardization methods: The method presumes that all trees in a population have a common age/sizerelated growth trend that can be empirically determined by aligning tree-ring samples according to their cambial age and calculating the average of rings 1; rings 2 ; etc. Hence, the cambial age of all tree rings must be known, i.e. samples should ideally include the pith (the centre of the tree). When the pith is absent, which often is the case in drilled core samples and subfossil wood, the pith offset (PO) has to be estimated. Here, PO was determined by first interpolating the distance to the geometric centre of the tree using the curvature of the innermost rings and then estimating the number of rings that would fill the missing segment. In the Torneträsk MXD data, the pith was present in 25 of the samples and PO was estimated in the remaining 75 samples. The 620 TRW samples were not adjusted for PO: Here, the first ring in the series is simply assumed to represent the ring of the first cambial year.

When averaging all individual tree-ring series according to their cambial age rather than their calendar year and calculating the average growth, it is also presumed that the influence from climate forcing will be levelled out. Therefore, when using the RCS method, it is critically important that there is a wide distribution of the data over time, i.e. the data lined up for each cambial year should ideally come from a wide range of climatic conditions. To avoid the bias introduced by an insufficient number of replicate samples, therefore, only data where the sample depth $\geq 25$ were used to calculate the average curve
(Fig. 4). A smoothed "Hugershoff" version (Warren 1980) of the average curves was then used for the RCS standardization.

After standardization, each individual series is realigned according to the calendar age and an arithmetic mean series is calculated. Figure 5 shows the RCS standardized index chronologies for MXD and TRW. The signal strength and confidence in these chronologies is assessed by calculating R-BAR and expressed population signal (EPS) statistics in a 50-year window moved in 25year steps over the total length of the series (Wigley et al. 1984). The R-BAR statistic is a measure of the average inter-correlation of all overlapping series, while EPS denotes the percent common signal. EPS is related to RBAR and to the number of replicate series, with EPS values above 0.85 generally regarded as satisfactory (Wigley et al. 1984). Figure 5 shows that although the R-BAR values for the TRW chronology are lower and more variable as compared to the MXD chronology, the confidence in the TRW signal is much higher, with EPS values typically above 0.95 as a result of the much higher sample replication in the TRW chronology. In the MXD chronology, EPS is on average 0.89 , but with critically low values in some periods, particularly at $\mathrm{AD} 650,1025,1275$ and 1425 .

The significance of the century-timescale variation observed in the chronologies is assessed by, first, smoothing all individual index series with a 100-year spline filter, thus generating a new set of low-frequency series which are, then, averaged into a low-frequency chronology
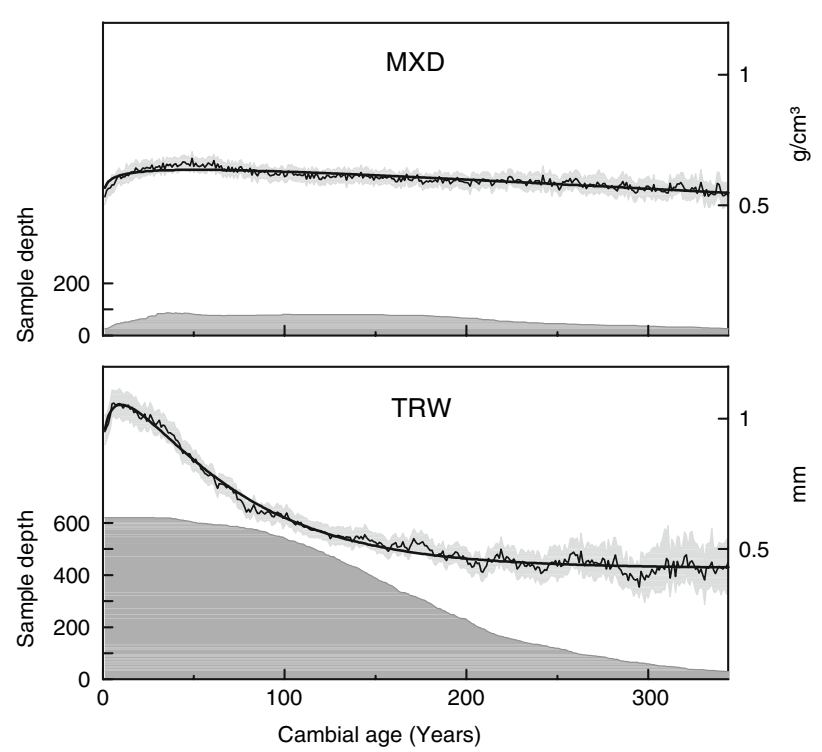

Fig. 4 Regional growth curves used for the RCS standardization (thick black) plotted on top of the annually averaged growth values (thin black) and the 95\% confidence interval (light grey shading). The lower part of each panel shows the sample depth (dark grey shading) 
(Sheppard 1991). Using this approach, it is possible to calculate bootstrapped $95 \%$ confidence intervals for the century timescale variation and hence visualize sections of the chronologies where poor sample replication and/or low signal-to-noise ratio results in a weakening of the lowfrequency signal. Figure 5 shows that there is a higher confidence in the low-frequency signal in the TRW chronology. It is also evident that the low-frequency signals are very similar in the two chronologies up to about AD 1800 where there is a clear diversion between the trends.

\subsection{Tree-growth response to climate}

Three different sets of instrumental monthly mean climate data (Fig. 6) were used in order to identify climatic signals in the MXD and TRW chronologies and to investigate the optimum season for a climate reconstruction: (1) Abisko, a local record (AD 1913-2004) provided by Abisko Scientific Research Station (http://www.ans.kiruna.se), which is located within the Torneträsk area (Andersson et al. 1996); (2) Tornedalen, a long composite record (AD 1802-2002) based on a combination of historical data and synoptic
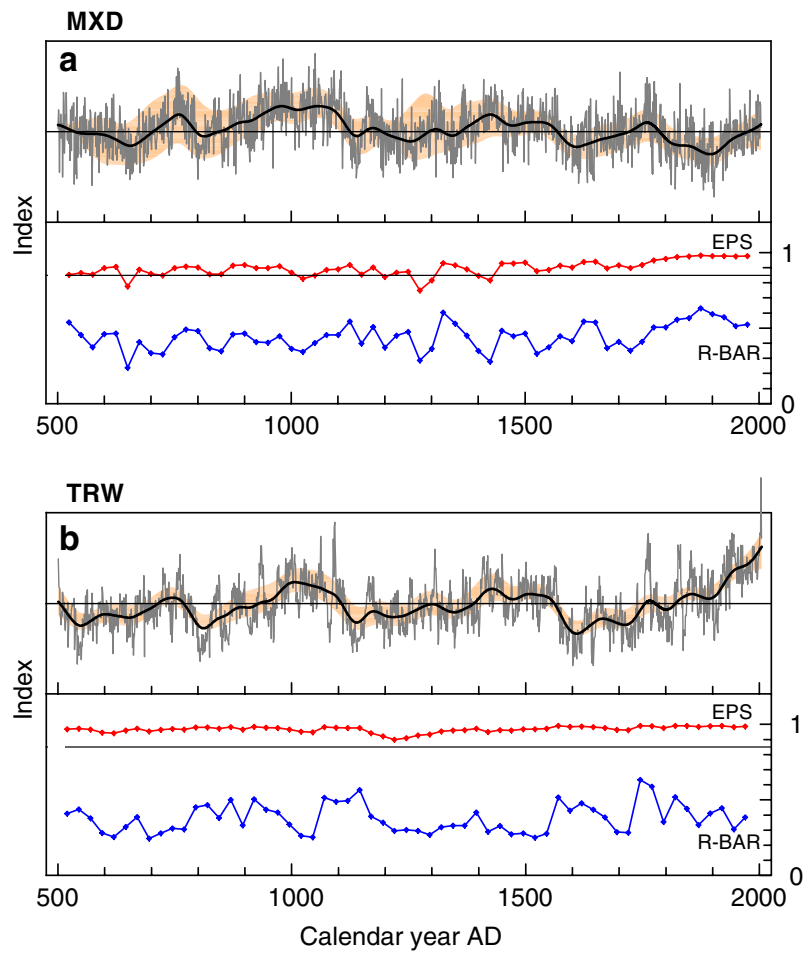

Fig. 5 RCS standardized chronologies (grey curves) for a MXD and b TRW, with their corresponding EPS (red) and $r$-bar (blue) values plotted for 50-year windows with 25 years overlap. The thick black curves are the average low-frequency variation in the individual index series (i.e. calculating the arithmetic mean after filtering each index series with a 100-year spline filter). The $95 \%$ confidence interval around the low-frequency signal is indicated by the sand-coloured shading station data from Haparanda $\left(65^{\circ} 49^{\prime} \mathrm{N}, 24^{\circ} 8^{\prime} \mathrm{E}\right)$ approx. $350 \mathrm{~km}$ south-east of Torneträsk (Klingbjer and Moberg 2003); and (3) Bottenviken, a regional record (AD 18602004) provided by the Swedish Meteorological and Hydrological Institute (SMHI) and based on data from six synoptic stations in northern Sweden (Alexandersson 2002). The Bottenviken record includes data from both Abisko and Haparanda.

Response function analyses (Fritts 1976) were carried out using the climate data and the RCS standardized TRW and MXD chronologies. This involves calculating principal components (PC's) of monthly temperature and precipitation data and regressing the PC's on the annual tree-ring indices over a common period. In response functions, however, normal significance levels of coefficients may be misleading because error estimates are underestimated (Cropper 1985). Hence, the method used here involves the technique of bootstrapped confidence intervals to estimate the significance of both correlation and response function coefficients (Biondi and Waikul 2004) which produces more robust results (Guiot 1990, 1991). The response function analysis gives an indication of the direction and relative strength of the climatic forcing and the results show that both MXD and TRW have a significant positive response to growing-season temperatures (Fig. 7). There is no significant response to monthly sums of precipitation.

Local (Abisko) summer temperatures have a positive effect on both MXD and TRW, but the significant response time-window is much broader for MXD. For TRW, forcing is dominated by July temperatures of the current year of growth while MXD has a significant positive response to June, July and August temperatures of the current growing season. When analysed with the regional (Bottenviken) record, the response window for MXD is even broader including spring temperatures (April and May).

TRW also show significant response values to May and June temperatures of the previous year which reflects the high auto-correlation usually found in TRW chronologies (Fritts 1976). Therefore, a lagged TRW-variable must be included in the linear regression model for summer temperature reconstruction:

$C_{t}=a \bar{I}_{t}^{\mathrm{MXD}}+b \bar{I}_{t}^{\mathrm{TRW}}+c \bar{I}_{t+1}^{\mathrm{TRW}}+d$,

where $C_{t}$ is the reconstructed temperature in calendar year $t ; \bar{I}_{t}^{\mathrm{MXD}}$ is the MXD chronology index in year $t ; \bar{I}_{t}^{\mathrm{TRW}}$ and $\bar{I}_{t+1}^{\mathrm{TRW}}$ are the TRW chronology indices in years $t$ and $t+1$; $a-d$ are the regression coefficients.

The fidelity of the reconstruction equation was then tested in a calibration/verification exercise (Fritts 1976; Cook and Kairiukstis 1990) where the Bottenviken mean summer (April-August) temperature was split into two independent 72-year periods. Equation (3) was fitted over one period using linear regression, and with the derived 


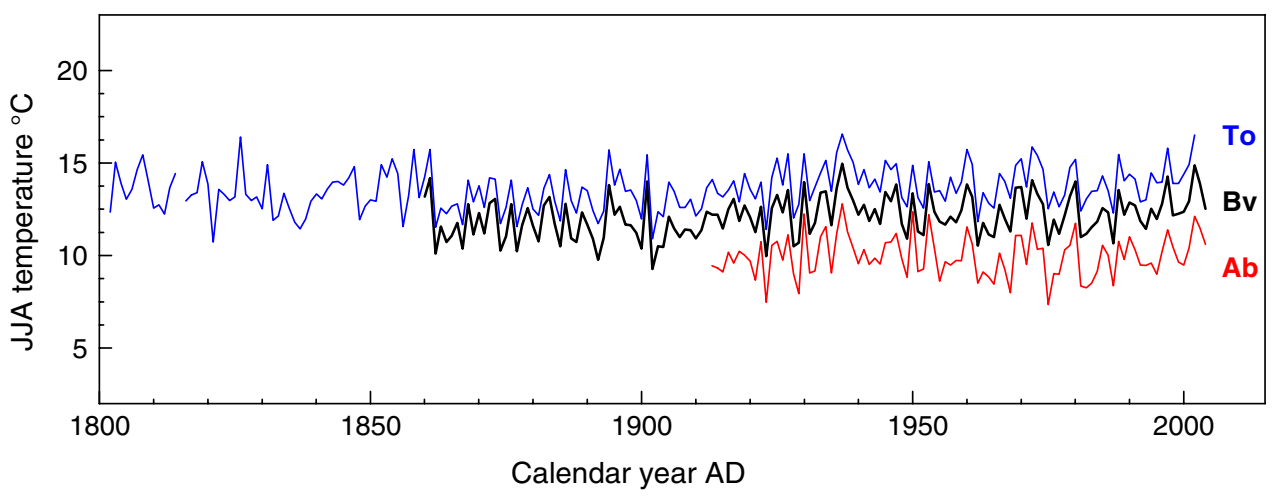

Fig. 6 Three different sets of monthly climate data was used in this study: Abisko Scientific Research Station $(\mathrm{Ab})$, located in the Torneträsk area; Bottenviken $(\mathrm{Bv})$, which is a regional record of instrumental data from six stations in northern Sweden; and
Tornedalen (To), which is a composite record of instrumental and historical climate data. Shown here are the average June-August temperatures
Fig. 7 Climatic forcing on MXD and tree-ring width (TRW) using monthly mean temperature from Abisko $(\mathbf{a}, \mathbf{b})$, Bottenviken (c, d), and Tornedalen $(\mathbf{e}, \mathbf{f})$. The bars indicate the direction and strength of the climate forcing, expressed as bootstrapped response values. The horizontal lines indicate the $95 \%$ confidence limit. The grey bars show the response values for the 12 months of the current year, while the white bars show the response from the year prior to growth
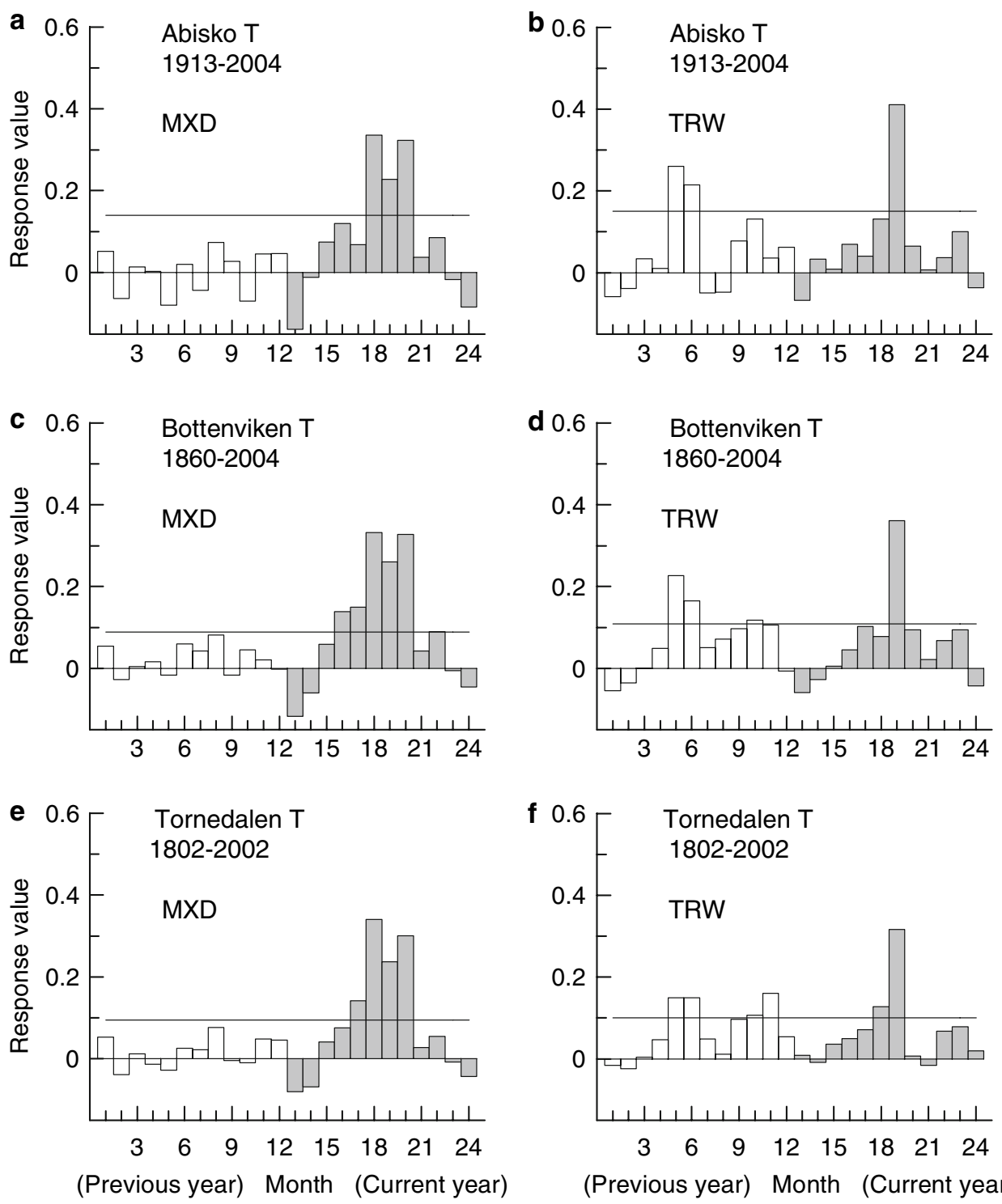

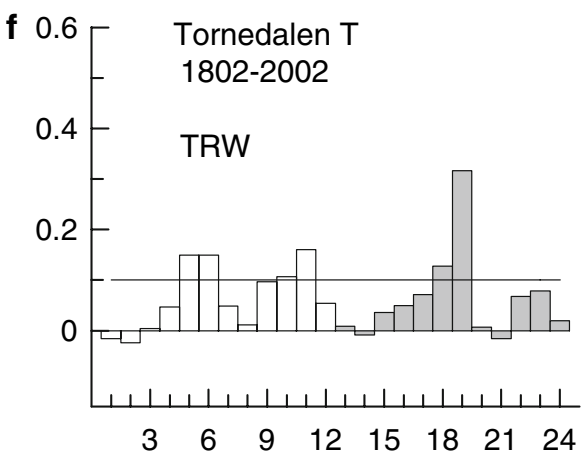

(Previous year) Month (Current year) 
coefficients applied to the tree-ring data in the other period. This calibration/verification scheme produces independent estimates of temperature that can be compared to the instrumental temperature data. The procedure was applied using the TRW and MXD chronologies combined, and repeated for the TRW chronology and the MXD chronology individually (Fig. 8). The verification results were tested using the squared Pearson correlation $\left(R^{2}\right)$, the reduction of error (RE), and the coefficient of efficiency (CE) (Table 2). The $R^{2}$ statistic, ranging from 0.0 to 1.0 , is a measure of the proportion of variation "explained" by the regressors in the model. The RE and the CE statistics both range from $-\infty$ to +1.0 with $\mathrm{RE}>\mathrm{CE}$ and where values greater than 0 give confidence to the model performance (Fritts 1976; Briffa et al. 1988). Of these three statistics, CE is the most difficult to pass (Cook et al. 1994). The TRW chronology used alone give poor results $(\mathrm{CE}=0.17$; 0.27). When the TRW and MXD chronologies are used in a multiple regression the verification results improve significantly $(\mathrm{CE}=0.37 ; 0.49)$. The best verification results are obtained with the MXD chronology alone $(\mathrm{CE}=0.55$; $0.54)$.

Hence, based on the verification results, a reconstruction using the MXD chronology alone should give the best results. However, the stronger low-frequency signal strength in the TRW chronology (Fig. 5) indicates that there is useful information to be gained by including also the TRW chronology in the reconstruction. The low frequency variation in these two chronologies is very similar for the first 1,300 years of the records. Around AD 1800, however, the trends in MXD and TRW start to diverge significantly with the largest diversion occurring in the

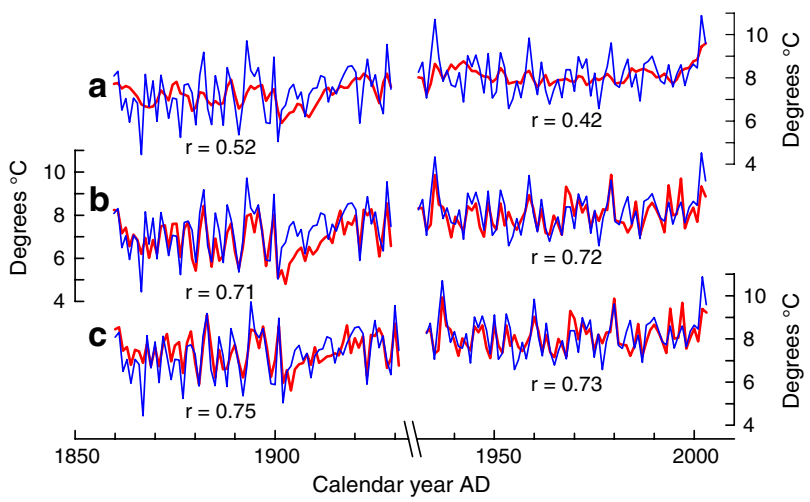

Fig. 8 The regression equation (Eq. 3) was tested in a cross calibration/verification exercise using the RCS-chronologies and Bottenviken mean summer (April-August) temperature. The test was repeated for a TRW exclusively; $\mathbf{b}$ TRW + MXD; and $\mathbf{c}$ MXD exclusively. The data were split in two 72-year periods: 1860-1931 and 1932-2003. The regression coefficients derived from the first period were used to reconstruct temperatures in the second period, and vice versa, thus producing two sets of independent data. The instrumental temperature is shown in blue and estimates in red early nineteenth century (Fig. 9). The diverging trends could, potentially, be caused by a change in the sensitivity to summer temperature of one, or both, of these growth parameters. To examine the nature of this "divergence problem" the 200-year long Tornedalen record of JuneAugust mean temperature was divided in four 50-year segments and compared individually to the standardized TRW and MXD series (Fig. 10). The results show that the correlation between TRW and summer temperature is very low $(R=0.20)$ in the first 50-year period (AD 1802-1852) while it is significantly higher and relatively consistent in the following three periods $(0.47 ; 0.58 ; 0.47)$. For MXD, the correlations are much higher $(R=0.70-0.81)$ and with no obvious inconsistency in the response to summer temperature between the four periods. Hence, the "divergence problem" seems to be isolated to TRW in the first half of the nineteenth century.

\subsection{AD 500-2004 climate reconstruction}

Two reconstructions of summer temperature were made using regression weights for the Bottenviken April-August mean temperature and the full 1860-2004 calibration period (Table. 2): A reconstruction based on MXD exclusively (Fig. 11a), and a "multi-proxy" reconstruction based on TRW and MXD (Fig. 11b). The reconstructions are expressed as temperature $\left({ }^{\circ} \mathrm{C}\right)$ anomalies from the $\mathrm{AD}$ 1951-1970 baseline period which enables the new results to be directly compared with previously published reconstructions from Torneträsk (Briffa et al. 1992; Grudd et al. 2002).

The two new reconstructions show summer temperature variation over the last 1,500 years. The maximum amplitude is about $5^{\circ} \mathrm{C}$ with the warmest summers occurring around $\mathrm{AD} 1000$ and the coldest summers occurring around AD 1900. Figure 11c shows that the two reconstructions are very similar on decadal-to-centennial timescales. On these timescales, notably cold periods occur around AD 650, 800, $1150,1250,1350,1600$ and 1900 . Notably warm periods occur around $\mathrm{AD} 750,1000,1400,1750$ and 2000. The 200year long warm period centred on $\mathrm{AD} 1000$ is especially noticeable. With a $95 \%$ confidence interval applied to the low-frequency (century timescale) signal, this period is significantly warmer than the late twentieth century (Fig. 12).

\section{Discussion}

The new tree-ring data presented in this paper update the Torneträsk chronologies to $\mathrm{AD} 2004$, thus extending the MXD record with 24 years and the TRW record with 
Table 2 Calibration and verification results

\begin{tabular}{|c|c|c|c|c|c|c|c|c|c|}
\hline \multirow[b]{2}{*}{ Calibration period } & \multicolumn{3}{|l|}{ TRW } & \multicolumn{3}{|c|}{ TRW + MXD } & \multicolumn{3}{|l|}{ MXD } \\
\hline & $1860-1931$ & $1932-2003$ & $1860-2003$ & $1860-1931$ & $1932-2003$ & $1860-2003$ & $1860-1931$ & $1932-2003$ & 1860-2004 \\
\hline Correlation $R$ & 0.43 & 0.53 & 0.59 & 0.75 & 0.80 & 0.80 & 0.75 & 0.74 & 0.79 \\
\hline Explained variance $R^{2}$ & 0.18 & 0.28 & 0.35 & 0.57 & 0.64 & 0.64 & 0.56 & 0.54 & 0.63 \\
\hline Observations & 72 & 72 & 144 & 72 & 72 & 144 & 72 & 72 & 145 \\
\hline \multicolumn{10}{|l|}{ Regression weights } \\
\hline $\mathrm{TRW}_{t}$ & 1.278 & 1.268 & 1.248 & -0.387 & 0.382 & -0.041 & - & - & - \\
\hline $\mathrm{TRW}_{t+1}$ & 0.995 & 1.375 & 1.162 & 0.057 & 1.139 & 0.536 & - & - & - \\
\hline $\mathrm{MXD}_{\mathrm{t}}$ & - & - & - & 9.917 & 7.839 & 8.523 & 9.384 & 8.939 & 9.419 \\
\hline Constant & 4.828 & 4.334 & 4.677 & -1.367 & -1.851 & -1.019 & -1.240 & -0.742 & -1.242 \\
\hline Verification period & $1932-2003$ & $1860-1931$ & - & $1932-2003$ & $1860-1931$ & - & $1932-2003$ & $1860-1931$ & - \\
\hline Explained variance $\mathrm{R}^{2}$ & 0.27 & 0.18 & - & 0.50 & 0.52 & - & 0.56 & 0.54 & - \\
\hline Reduction of error RE & 0.50 & 0.63 & - & 0.62 & 0.75 & - & 0.73 & 0.77 & - \\
\hline Coeff. of efficiency CE & 0.17 & 0.27 & - & 0.37 & 0.49 & - & 0.55 & 0.54 & - \\
\hline
\end{tabular}

Summary of the calibration/verification results for the two separate periods (1860-1931 and 1932-2004) and for the full 1860-2004 period using Bottenviken April-August mean temperature and overlapping tree-ring data

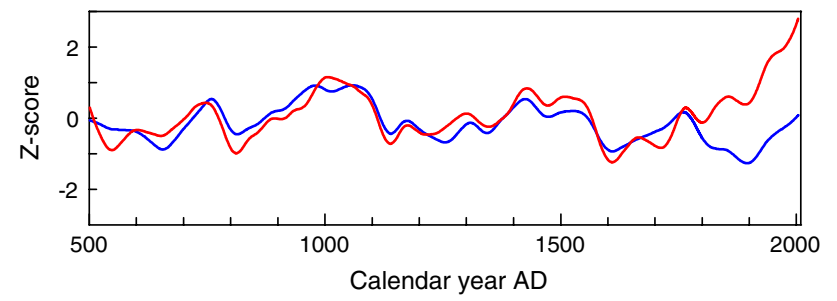

Fig. 9 The RCS standardized chronologies of TRW (red) and MXD (blue) were forced to have the same mean and standard deviation over the period AD 500-1500. The data were then filtered using a 100-year spline

7 years as compared to previously existing data (Schweingruber et al. 1988; Grudd et al. 2002). This update significantly extends the calibration time-period and improves the analysis of growth response to climate. Using overlapping instrumental climate data and response function analysis, it is established that Torneträsk MXD and TRW have a positive correlation to local summer temperature and that there is no significant correlation to precipitation. TRW is predominantly correlated to July mean temperature while MXD has a wider response window, including also June and August. This is in line with previous results from northern Fennoscandia which show a similar growth response to local climate (Sirén 1961; Jonsson 1969; Aniol and Eckstein 1984; Briffa et al. 1990; Lindholm and Eronen 1995; Kirshhefer 2001; Grudd et al. 2002; McCarroll et al. 2003). However, when the new Torneträsk data is analysed using a regional temperature record representing a large area in northern Sweden, there is a significant growth response to an extended five-month summer season, including also April and May (Fig. 7), thus confirming the results from Briffa et al. (1990) who found a significant correlation with April-August temperatures using gridded $\left(5^{\circ} \times 5^{\circ}\right)$ temperature data for northern Fennoscandia. Hence, when the Torneträsk tree-ring data is used to reconstruct regional summer temperatures, it is justified to use the April-August season.

Diverging trends between tree-ring chronologies and temperature in the late twentieth century have been observed across the high latitudes of the Northern Hemisphere (see D'Arrigo et al. 2007 and references therein). This apparent widespread loss in the sensitivity to temperature is, however, not fully understood and several different explanations have been proposed, e.g. relating the phenomenon to changes in the atmospheric composition (Briffa et al. 1998b, 2004); to drought stress (Barber et al. 2000); physiological threshold effects (D'Arrigo et al. 2004; Wilmking et al. 2004); and to changes in the length of the growing season (Vaganov et al. 1999). However, such "end effects" or biased trends in a tree-ring chronology could, potentially, also be related to the methodology used for standardization and chronology development (Cook and Peters 1997; Melvin 2004). The update of the Torneträsk data, including relatively young trees in the most recent period, has significantly reduced the mean cambial age of MXD data in the twentieth century (Fig. 1a). As a result, the loss of sensitivity to temperature, apparent in earlier versions of the Torneträsk MXD chronology (Briffa 2000), is now eliminated. Hence, this study shows that data with a disproportionately high cambial age in the most recent period can create a similar "divergence phenomenon" in the late twentieth century. This calls for further investigations of the age structure in other MXD data series that show a similar phenomenon. It 
Fig. 10 Correlations between Tornedalen summer (JuneAugust) temperature and RCS standardized TRW (top four panels) and MXD (bottom four panels). The data are split in four 50-year consecutive periods from $\mathrm{AD} 1802-2002$
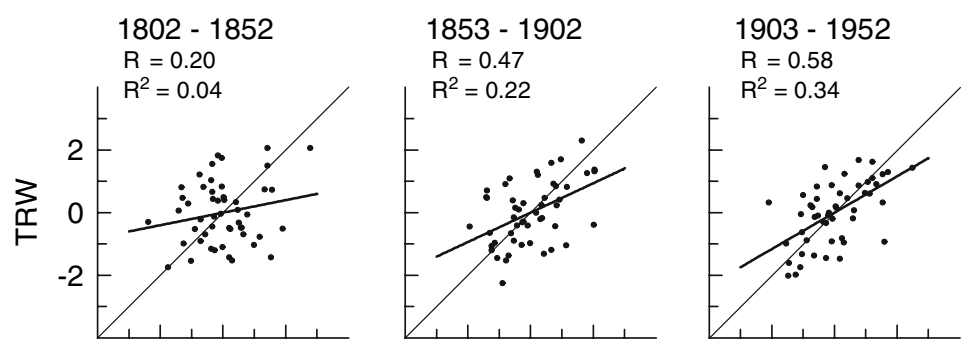

$1953-2002$

$\mathrm{R}=0.47$
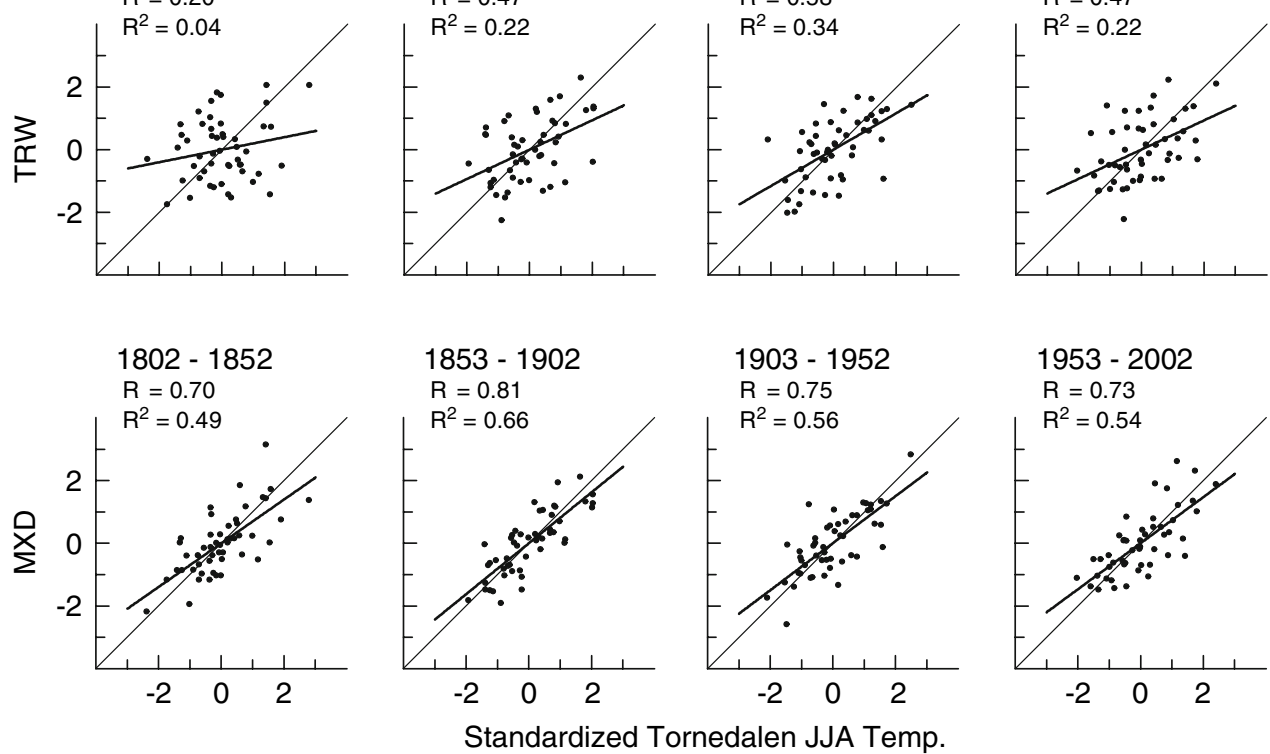

$1953-2002$

$\mathrm{R}=0.73$

$R^{2}=0.54$

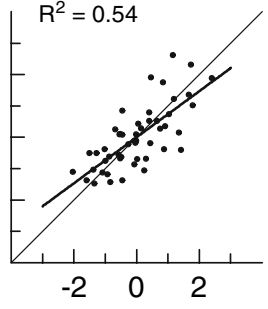

should, however, also be noted that the increasing trend in cambial age, still present in the Torneträsk MXD data from AD 500 to 1000 (Fig. 1a), is likely to produce a minor bias in the earliest part of the record (Melvin 2004).

Diverging trends between Torneträsk MXD and TRW are apparent around AD 1800 (Fig. 9). This was registered also by Briffa et al. (1992) who interpreted the phenomenon as a loss in the sensitivity of MXD to temperature and, therefore, made an adjustment to the trend in MXD for the period AD 1750-1980. However, when the tree-ring data is compared to the 200-year long temperature record from Tornedalen it clearly shows, on the contrary, that the diverging trends are caused by the TRW data (Fig. 10). The correlations between MXD and temperature are consistent between the four 50-year periods, while TRW shows a poor correlation in the first period and then higher and fairly consistent correlations in the following three periods. Hence, there is an apparent loss in the sensitivity of TRW to temperature in the first half of the nineteenth century. The phenomenon coincides with an important regeneration period in the Torneträsk area, expressed as a doubling of the sample replication at this time (Fig. 1b). It seems likely, therefore, that the diverging trend in TRW is related to changes in stand dynamics at this time. Helama et al. (2004a, 2005) have shown that such a major increase in population density could affect the empirically determined growth curves used in normal RCS standardization. The effect will be larger for the more concave RCS curves used for TRW (Fig. 4), which would explain why the MXD chronology is unaffected. Hence, pending further investigations, the diverting trend in TRW around AD 1800 is regarded as a bias introduced by the data and the standardization methods used.

The calibration/verification results (Table 2) indicate that a reconstruction based exclusively on MXD will give the most accurate temperature estimates. The calibration/ verification results are, however, dominated by the interannual variability, and given the higher significance for low-frequency variation in the TRW chronology and the importance of getting the longer timescales right, a complementary "multi-proxy" reconstruction was produced based on a combination of TRW and MXD (Fig. 11). The low-frequency signal is virtually identical in the two reconstructions, with the multi-proxy reconstruction showing slightly deflated temperature estimates in the pre1800 period due to the bias introduced by the diverging TRW trend. On average, the difference is only about $0.2^{\circ} \mathrm{C}$ which, again, reflects the strong dominance of MXD over TRW in reconstructions based on these two tree-ring parameters. For the further comparison with other paleoclimate data, therefore, the MXD reconstruction is used; although the reader should take note that the relatively low sample replication in the MXD data generally gives a wider error band (Fig. 5).

Previously published summer temperature reconstructions based on Torneträsk tree-ring data (Briffa et al. 1992; Grudd et al. 2002) have recovered, at best, 55\% of the inter-annual variance in the instrumental temperature data; the new MXD reconstruction captures $63 \%$ (Table 2). The new reconstruction shows much warmer temperature estimates as compared to Grudd et al. (2002) and generally warmer and more low-frequency variability as compared to 


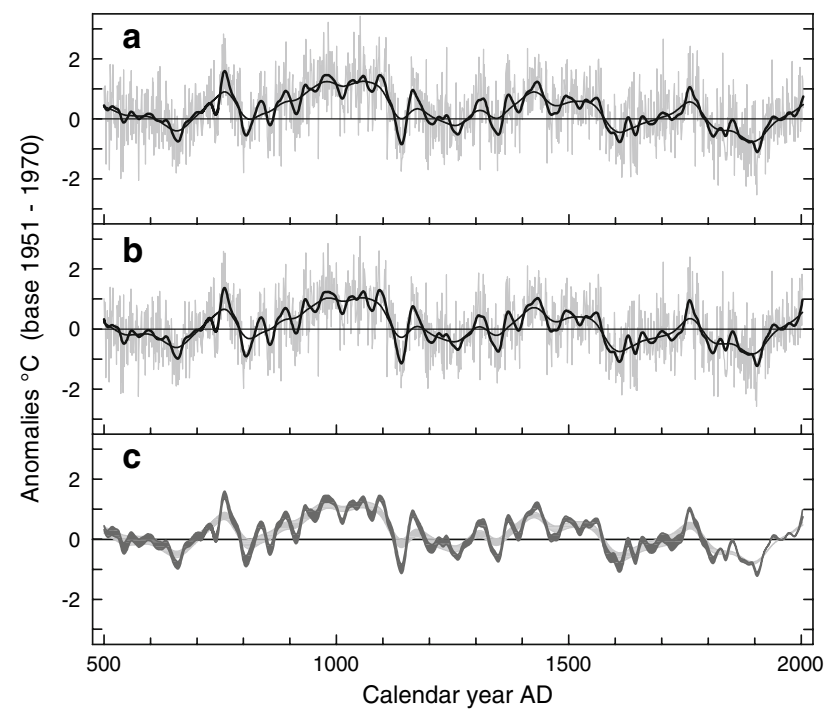

Fig. 11 Reconstructed summer (April-August) temperature for the period AD 500-2004. Panel a shows the reconstruction from MXD exclusively. Panel b shows the "multi-proxy" reconstruction from MXD + TRW. Both series are expressed as anomalies (in ${ }^{\circ} \mathrm{C}$ ) from their 1951-1970 mean. The annual data (grey) has been filtered to emphasize climatic variability on 30- and 100-year timescales (black curves). Panel c shows the difference on multi-decadal (dark grey) and centennial (light grey) timescales between the two reconstructions (expressed as an in-between fill of the curves), with the "multiproxy" reconstruction showing on average $0.2^{\circ} \mathrm{C}$ lower temperature estimates

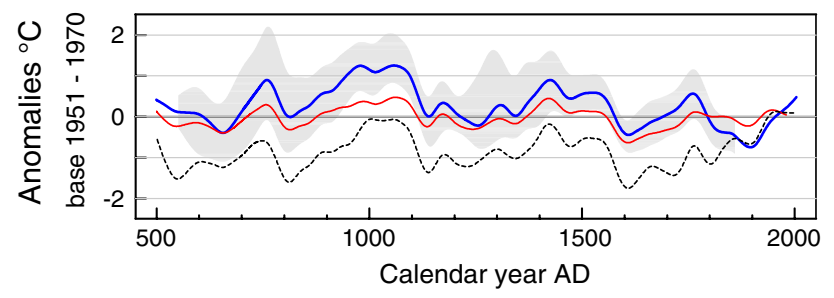

Fig. 12 The thick blue curve is the new Torneträsk MXD lowfrequency reconstruction of April-August temperatures, with a 95\% confidence interval (grey shading) adopted from Fig. 5. The new record is compared with two previously published temperature reconstructions based on tree-ring data from Torneträsk: The thin red curve is from Briffa et al. (1992) and based on TRW and MXD. The hatched curve is from Grudd et al. (2002) and based on TRW. The three reconstructions were equally smoothed with a 100 -year spline filter and have AD 1951-1970 as a common base period

Briffa et al. (1992) (Fig. 12). The reconstruction from Grudd et al. (2002) was based on RCS standardized TRW and, hence, the large difference prior to $\mathrm{AD} 1800$ can be explained by the "divergence problem" in TRW. Briffa et al. (1992) used RCS standardized MXD and TRW in a multi-proxy approach. However, their application of a "trend adjustment" to the MXD data introduced a bias towards lower temperature estimates prior to 1750 .

A major difference between the new record and the earlier summer temperature reconstructions is the timing of the coldest and the warmest century timescale periods in the last 1,500 years: The earlier reconstructions have minimum temperatures around AD 1600 while the coldest period in new reconstruction is centred on AD 1900. This "late" cold period coincides with historical and proxy evidence of maximum Holocene glacier expansion in northern Sweden (Svenonius 1910; Enquist 1918; Karlén 1988) and marks the culmination of the "Little Ice Age" (Grove 1988). A late "Little Ice Age" period is seen also in pollen and diatom proxy records from northern Fennoscandia (Korhola et al. 2000; Weckström et al. 2006) although it is less precisely dated. The differences between the new reconstruction and Briffa et al. (1992) are especially significant in the 200-year warm period centred on AD 1000 which coincides with the so called "Medieval Warm Period" (Lamb 1966). A warm period around AD 1000 is in line with evidence from other proxy indicators from northern Fennoscandia: Pine tree-limit (Shemesh et al. 2001; Helama et al. 2004b; Kulti et al. 2006), pollen and diatoms (Korhola et al. 2000; Seppä and Birks 2002; Bigler et al. 2006) show indisputable evidence of a "Medieval Warm Period" that was warmer than the twentieth century climate. Furthermore, the records of Late Holocene glacier variability in Scandinavia show that glaciers were reduced in size C. AD 900-1000 and that a warm climate prompted the development of soils on the glacier forfields (Karlén and Denton 1975; Worsley and Alexander 1976; Griffey and Matthews 1978; Matthews 1980; Karlén 1982; Hormes et al. 2004). The new evidence presented by Torneträsk tree-rings, indicates that the "Medieval Warm Period" in northern Fennoscandia may have been considerably warmer than previously recognized.

Long TRW records from an adjacent area in northern Finland (Helama et al. 2002) as well as more distant areas in Siberia (Hantemirov and Shiyatov 2002; Naurzbaev et al. 2002) indicate warm conditions around $A D 1000$ and around $\mathrm{AD} 1400$, concurrent with the warm periods in the Torneträsk record. A long TRW chronology from northern Norway (Kirchhefer 2005) shows an early "Medieval Warm Period" around AD 900 and warm conditions around $\mathrm{AD}$ 1400. In contrast to the new Torneträsk MXD reconstruction, however, these TRW records indicate that twentieth century temperatures were unprecedented in the last 1,500 years. All tree-ring records, including the Torneträsk record, show an abrupt climatic deterioration in the twelfth century which supports other evidence of an early initiation of the "Little Ice Age" in the North Atlantic region (Grove 2001).

The new Torneträsk summer temperature reconstruction shows a trend of $-0.3^{\circ} \mathrm{C}$ over the last 1,500 years. A similar negative trend is seen in most other Holocene paleoclimate records from northern Sweden, e.g. changes in 
tree-limit (Karlén 1976; Kullman 1995); pollen (Barnekow 1999); chironomids (Larocque and Bigler 2004); oxygenisotopes in lacustrine biogenic silica (Shemesh et al. 2001) and in lacustrine carbonates (Hammarlund et al. 2002). A negative trend is also seen in oxygen isotope records in Greenland ice cores (NGRIP-members 2004), which implies that the proxy records from northern Sweden display a general feature of Holocene climate in the North Atlantic region, possibly linked to orbital forcing of summer insolation.

Although the paleoclimatic records show a high degree of similarity in North Fennoscandian and, possibly, North Atlantic trends over the last millennia, it is important to also note that there are large regional differences in the timing and the magnitude of climatic periods such as the "Medieval Warm Period" (Hughes and Diaz 1994; Crowley and Lowery 2000) and the "Little Ice Age" (Bradley 1992; Jones and Briffa 2001). Hence, although the climate of northern Fennoscandia seems to have been significantly warmer during medieval times as compared to the late-twentieth century, the published composite records of northern hemisphere climate (Moberg et al. 2005) do not show a conspicuously warm period around AD 1000.

It is shown here, that temperature estimates based on Torneträsk TRW are biased around AD 1800. This bias is most probably linked to changes in stand dynamics at this time and to the methods used for standardization. Other TRW records from northern tree-line areas may well share the same phenomenon, which calls for further investigations on the link between stand dynamics and climate growth-response. It is also demonstrated here, that MXD have a much more sensitive and robust coupling to summer temperature. It is, therefore, important that efforts are made to complement the Torneträsk MXD data with updated and extended MXD records from other climate sensitive areas in the North if we are to capture the full amplitude of past temperature variability and increase our confidence in reconstructions of Northern Hemisphere climate change over the last millennium.

\section{Conclusions}

The Torneträsk records of MXD and TRW are updated to AD 2004. By including MXD data from relatively young trees in the most recent period, a previously noted apparent loss of sensitivity to temperature is eliminated. These new data enable a much improved reconstruction of summer temperature for the last 1,500 years in northern Fennoscandia.

Previous climate reconstructions based on tree-ring data from Torneträsk were biased by a divergence phenomenon in TRW around AD 1800 and therefore show erroneously low temperature estimates in the earlier part of the records. Torneträsk MXD does not show this "divergence problem" and hence produces robust estimates of summer temperature variation on annual to multi-century timescales.

The late-twentieth century is not exceptionally warm in the new Torneträsk record: On decadal-to-century timescales, periods around $\mathrm{AD}$ 750, 1000, 1400, and 1750 were all equally warm, or warmer. The warmest summers in this new reconstruction occur in a 200-year period centred on AD 1000. A "Medieval Warm Period" is supported by other paleoclimate evidence from northern Fennoscandia, although the new tree-ring evidence from Torneträsk suggests that this period was much warmer than previously recognised.

Acknowledgments I acknowledge P. Kuhry, B. Luckman, A. Hofgaard, K. Nicoluss, M. Hansson, D. McCarroll, and three anonymous reviewers for substantial improvements to the manuscript. $\mathrm{H}$. Samulesson and staff at the Abisko Research Station provided help in the field and in the laboratory, and A. Rindby of Cox Analytical Systems has provided invaluable technical support. I would also like to thank K. Briffa and T. Melvin for productive comments on the results. This research was financed by EU projects PINE (Contract No EVK2-CT-2002-00136) and Millennium (Contract No 017008 GOCE).

Open Access This article is distributed under the terms of the Creative Commons Attribution Noncommercial License which permits any noncommercial use, distribution, and reproduction in any medium, provided the original author(s) and source are credited.

\section{References}

Alexandersson H (2002) Temperature and precipitation in Sweden 1860-2001. SMHI Meteorologi, 104

Andersson NA, Callaghan TV, Karlsson PS (1996) The Abisko Scientific Research Station. Ecol Bull 45:11-14

Aniol RW, Eckstein D (1984) Dendroclimatological studies at the northern timberline. In: Mörner N-A, Karlén W (eds) Climatic Changes on a Yearly to Millennial Basis. D. Reidel Publ., Dordrecht, pp 273-279

Barber VA, Juday GP, Finney BP (2000) Reduced growth of Alaskan white spruce in the twentieth century from temperature-induced drought stress. Nature 405:668-673

Barnekow L (1999) Holocene tree-line dynamics and inferred climatic changes in the Abisko area, northern Sweden, based on macrofossil and pollen records. Holocene 9:253-265

Bartholin TS (1987) Dendrochronology in Sweden. Annal Acad Sci Fenn 145:79-88

Bigler C, Barnekow L, Heinrichs ML, Hall RI (2006) Holocene environmental history of Lake Vuolep Njakajaure (Abisko National Park, northern Sweden) reconstructed using biological proxy indicators. Veg Hist Archaeobotany 15:309-320

Biondi F, Waikul K (2004) DENDROCLIM2002: a C++ program for statistical calibration of climate signals in tree-ring chronologies. Comput Geosci 30:303-311

Bradley RS (1992) When was the "Little Ice Age"? In: Mikami T (ed) Proceedings of the international symposium on the little ice age climate. Department of Geography, Tokyo Metropolitan University, Tokyo 
Briffa KR (2000) Annual climate variability in the Holocene: intepreting the message of ancient trees. Quatern Sci Rev 19:87-105

Briffa KR, Osborn TJ (2002) Blowing hot and cold. Science 295:2227-2228

Briffa KR, Jones PD, Pilcher JR, Hughes MK (1988) Reconstructing summer temperatures in northern Fennoscandia back to A. D. 1700 using tree-ring data from Scots pine. Arct Alp Res 20:385394

Briffa KR, Bartholin TS, Eckstein D, Jones PD, Karlén W, Schweingruber FH, Zetterberg P (1990) A 1400-year tree-ring record of summer temperatures in Fennoscandia. Nature 346:434-439

Briffa KR, Jones PD, Bartholin TS, Eckstein D, Schweingruber FH, Karlén W, Zetterberg P, Eronen M (1992) Fennoscandian summer from $\mathrm{AD}$ 500: temperature changes on short and long timescales. Clim Dynam 7:111-119

Briffa KR, Schweingruber FH, Jones PD, Osborn TJ, Harris IC, Shiyatov SG, Vaganov EA, Grudd H (1998a) Trees tell of past climates: but are they speaking less clearly today? Philos Trans R Soc Lond B 353:65-73

Briffa KR, Schweingruber FH, Jones PD, Osborn TJ, Shiyatov SG, Vaganov EA (1998b) Reduced sensitivity of recent tree-growth to temperature at high northern latitudes. Nature 391:678-682

Briffa KR, Osborn TJ, Schweingruber FH, Jone PD, Shiyatov SG, Vaganov EA (2002a) Tree-ring width and density data around the northern hemisphere: part 1 , local and regional climate signals. Holocene 12:737-757

Briffa KR, Osborn TJ, Schweingruber FH, Jone PD, Shiyatov SG, Vaganov EA (2002b) Tree-ring width and density data around the northern hemisphere: part 2, spatio-temporal variability and associated climate patterns. Holocene 12:759-789

Briffa KR, Osborn TJ, Schweingruber FH (2004) Large-scale temperature inferences from tree rings: a review. Glob Planet Change 40:11-26

Cook E (1990) A conceptual linear aggregate model for tree rings. In: Cook E, Kairiukstis L (eds) Methods of dendrochronology: applications in the environmental science. Kluver Academic Publishers, Dordrecht, p 394

Cook ER, Kairiukstis LA (eds) (1990) Methods of dendrochronology: applications in the environmental science. Kluwer Academic Publishers, Dordrecht, p 394

Cook ER, Peters K (1997) Calculating unbiased tree-ring indices for the study of climatic and environmental change. Holocene 7:361-370

Cook E, Briffa KR, Shiyatov S, Mazepa V (1990) Tree-ring standardization and growth-trend estimation. In: Cook E, Kariukstis LA (eds) Methods of dendrochronology. Applications in the environmental sciences. Kluwer Academic Publishers, Dordrecht, pp 394

Cook ER, Briffa KR, Jones PD (1994) Spatial regression methods in dendroclimatology: a review and comparison of two techniques. Int J Climatol 14:379-402

Cook E, Esper J, D'Arrigo R (2004) Extra-tropical northern hemisphere land temperature variability over the past 1000 years. Quatern Sci Rev 23:2063-2074

Cropper JP (1985) Tree-ring response functions: an evaluation by means of simulations. Ph.D Thesis, University of Arizona, Tucson

Crowley TJ, Lowery TS (2000) How warm was the Medieval Warm Period? Ambio 29:51-54

D'Arrigo R, Jacoby G, Free M, Robock A (1999) Northern hemisphere temperature variability for the past three centuries: tree-ring and model estimates. Clim Change 42:663-675

D'Arrigo R, Wilson R, Jacoby G (2006) On the long-term context for late twentieth century warming. J Geophys Res 111:D03103
D'Arrigo R, Wilson R, Liepert B, Cherubini P (2007) On the 'divergence problem' in northern forests: a review of the treering evidence and possible causes. Glob Planet Change. Available online 24 March 2007

D’Arrigo RD, Kaufmann RK, Davi N, Jacoby GC, Laskowski C, Myneni RB, Cherubini P (2004) Thresholds for warminginduced growth decline at elevational tree line in the Yukon Territory, Canada. Global Biogeochemical Cycles, 18, GB3021. doi:10.1029/2004GB002249

Driscoll WW, Wiles GC, D'Arrigo RD, Wilmking M (2005) Divergent tree growth response to recent climatic warming, Lake Clark National Park and Preserve, Alaska. Geophys Res Lett 32:L20703. doi:10.1029/2005GL024258

Enquist F (1918) Die glaziale Entwicklungsgeschite Nordwestscandinaviens, Rep. No. C 285. Sveriges Geologiska Undersökning

Erlandsson S (1936) Dendro-chronological studies. Ph.D. thesis, University of Uppsala, Uppsala

Esper J, Cook ER, Schweingruber FH (2002) Low-frequency signals in long tree-ring chronologies for reconstructing past temperature variability. Science 295:2250-2253

Esper J, Cook ER, Krusic PJ, Peters K, Schweingruber FH (2003) Tests of the RCS method for preserving low-frequency variability in long tree-ring chronologies. Tree Ring Res 59:81-98

Esper J, Wilson RJS, Frank DC, Moberg A, Wanner H, Luterbacher J (2005) Climate: past ranges and future changes. Quatern Sci Rev 24:2164-2166

Fritts HC (1976) Tree rings and climate. Academic Press, London

Gouirand I, Linderholm HW, Moberg A, Wohlfarth B (2007) On the spatiotemporal characteristics of Fennoscandian tree-ring based summer temperature reconstructions. Theor Appl Climatol. doi: 10.1007/s00704-007-0311-7 (Epub ahead of print)

Griffey NJ, Matthews JA (1978) Major Neoglacial glacier expansion episodes in southern Norway: evidence from moraine ridge stratigraphy with ${ }^{14} \mathrm{C}$ dates on buried paleosols and moss layers. Geogr Ann 60A:73-90

Grove JM (1988) The Little Ice Age. Routledge, London

Grove JM (2001) The initiation of the "Little Ice Age" in regions round the North Atlantic. Clim Change 48:53-82

Grudd H, Briffa KR, Karlén W, Bartholin TS, Jones PD, Kromer B (2002) A 7400-year tree-ring chronology in northern Swedish Lapland: natural climatic variability expressed on annual to millennial timescales. Holocene 12:643-656

Guay R, Gagnon R, Morin H (1992) MacDENDRO and the concept of virtual slit for density measurements. In IUFRO ALLDIVISION 5 meeting, 23-28 August, Nancy, France

Guiot J (1990) Methods of calibration. In: Cook ER, Kairiukstis L (eds) Methods of dendrochronology. Kluwer, Dordrecht, pp 165-178

Guiot J (1991) The bootstrapped response function. Tree Ring Bull $51: 39-41$

Hammarlund D, Barnekow L, Birks HJB, Buchardt B, Edwards TWD (2002) Holocene changes in atmospheric circulation recorded in the oxygen-isotope stratigraphy of lacustrine carbonates from northern Sweden. Holocene 12:339-351

Hantemirov RM, Shiyatov SG (2002) A continuous multimillennial ring-width chronology in Yamal, northwestern Sibiria. Holocene 12:717-726

Helama S, Lindholm M, Timonen M, Meriläinen J, Eronen M (2002) The supra-long Scots pine tree-ring record for Finnish Lapland: part 2, interannual to centennial variability in summer temperatures for 7500 years. Holocene 12:681-687

Helama S, Lindholm M, Timonen M, Eronen M (2004a) Detection of climate signal in dendrochronological data analysis: a comparison of tree-ring standardization methods. Theor Appl Climatol 79:239-254

Helama S, Lindholm M, Timonen M, Eronen M (2004b) Dendrochronologically dated changes in the limit of pine in 
northernmost Finland during the past 7.5 millennia. Boreas 33:250-259

Helama S, Timonen M, Lindholm M, Meriläinen J, Eronen M (2005) Extracting long-period climate fluctuations from tree-ring chronologies over timescales of centuries to millennia. Int J Climatol 25:1767-1779

Hormes A, Karlén W, Possnert G (2004) Radiocarbon dating of paleosol components in moraines in Lapland, northern Sweden. Quatern Sci Rev 23:2031-2043

Hughes MK, Diaz HF (1994) Was there a "Medieval Warm Period", and if so, where and when? Clim Change 26:109-142

IPCC (2007) Climate change 2007: the physical science basis. Contribution of Working Group I to the fourth assessment report of the intergovernmental panel on climate change, Cambridge University Press, Cambridge, p 996

Jacoby GC, D'Arrigo R (1995) Tree-ring width and density evidence of climatic and potential forest change in Alaska. Global Biogeochem Cycles 9:227-234

Jones PD, Briffa KR (2001) The "Little Ice Age": local and global perspectives. Clim Change 48:5-8

Jones PD, Briffa KR, Barnett TP, Tett SFB (1998) High-resolution palaeoclimatic records for the last millennium: interpretation, integration and comparison with general circulation model control-run temperatures. Holocene 8:455-471

Jones PD, Osborn TJ, Briffa KR (2001) The evolution of climate over the last millennium. Science 292:662-667

Jonsson B (1969) Studier över den av väderleken orsakade variationen i årsringsbredderna hos tall och grani Sverige. (Studies of variations in the widths of annual rings in Scots pine and Norway spruce due to weather conditions in Sweden), Rep. No. 16. Department of Forest Yield Research, Royal Colleague of Forestry

Karlén W (1976) Lacustrine sediments and tree-limit variations as indicators of Holocene climatic fluctuations in Lappland: northern Sweden. Geogr Ann 58A:1-34

Karlén W (1982) Holocene glacier fluctuations in Scandinavia. Striae 18:26-34

Karlén W (1988) Scandinavian glacial and climate fluctuations during the Holocene. Quatern Sci Rev 7:199-209

Karlén W, Denton GH (1975) Holocene glacial variations in Sarek National Park, northern Sweden. Boreas 5:25-56

Kirshhefer AJ (2001) Reconstruction of summer temperature from tree-rings of Scots pine (Pinus sylvestris L.) in coastal northern Norway. Holocene 11:41-52

Kirchhefer AJ (2005) A discontinuous tree-ring record AD 320-1994 from Dividalen, Norway: inferences on climate and tree-line history. In: Broll G, Keplin B (eds) Mountain ecosystemsstudies in treeline ecology. Springer, Berlin, pp 219-235

Klingbjer P, Moberg A (2003) A composite monthly temperature record from Tornedalen in northern Sweden, 1802-2002. Int J Climatol 23:1465-1494

Korhola A, Weckström J, Holmström L, Erästö P (2000) A quantitative Holocene climatic record from diatoms in Northern Fennoscandia. Quatern Res 54:284-294

Kullman L (1995) Holocene tree-limit and climate history from the Scandes Mountains, Sweden. Ecology 76:2490-2502

Kulti S, Mikkola K, Virtanen T, Timonen M, Eronen M (2006) Past changes in the Scots pine forest line and climate in Finnish Lapland: a study based on megafossils, lake sediments, and GIS-based vegetation and climate data. Holocene $16: 381-391$

Lamb HH (1966) The changing climate. Methuen, London

Larocque I, Bigler C (2004) Similarities and discrepancies between chironomid- and diatom-inferred temperature reconstructions through the Holocene at Lake 850, northern Sweden. Quatern Int 122:109-121
Lindholm M, Eronen M (1995) A reconstruction of mid-summer temperatures from ring-widths of Scots pine since $A D 50$ in northern Fennoscandia. Geogr Ann 82A:527-535

Luterbacher J, Dietrich D, Xoplaki E, Grosjean M, Wanner H (2004) European seasonal and annual temperature variability, trends, and extremes since 1500. Science 303:1499-1503

Mann ME, Jones PD (2003) Global surface temperatures over the past two millennia. Geophys Res Lett 30:1820

Mann ME, Bradley RS, Hughes MK (1999) Northern hemisphere temperatures during the past millennium: inferences, uncertainties, and limitations. Geophys Res Lett 26:759-762

Mann ME, Hughes MK, Cook ER, Esper J (2002) Tree-ring chronologies and climate variability. Science $296: 848-849$

Matthews JA (1980) Some problems and implications of 14C dates from a podzol buried beneath an end moraine at Haugabreen, southern Norway. Geogr Ann 62A:185-208

McCarroll D, Jalkanen R, Hicks S, Tuovinen M, Gagen M, Pawellek F, Eckstein D, Schmitt U, Autio J, Heikkinen O (2003) Multiproxy dendroclimatology: a pilot study in northern Finland. Holocene 13:829-838

Melvin TM (2004) Historical growth rates and changing climatic sensitivity of boreal forests. Ph.D. thesis, University of East Anglia

Moberg A, Sonechkin DM, Holmgren K, Datsenko NM, Karlen W (2005) Highly variable northern hemisphere temperatures reconstructed from low- and high-resolution proxy data. Nature 433:613-617

Naurzbaev MM, Vaganov EA, Sidorova OV, Schweingruber FH (2002) Summer temperatures in eastern Taimyr inferred from a 2427-year late-Holocene tree-ring chronology and earlier floating series. Holocene 12:727-736

NGRIP-members (2004) North Greenland Ice Core Project Oxygene Isotope Data. IGBP PAGES/World Data Center for Paleoclimatology, Data Contribution Series \#2004-059. NOAA/NGDC PAleoclimatology Program, Boulder

Osborn TJ, Briffa KR (2004) The real color of climate change? Science 306:621-622

Schweingruber FH (1988) Tree rings: basics and applications of dendrochronology. Kluwer Academic Publishers, Dordrech

Schweingruber FH, Fritts HC, Bräker OU, Drew LG, Schär E (1978) The X-ray technique as applied to dendroclimatology. Tree Ring Bull 38:61-91

Schweingruber FH, Bartholin T, Schär E, Briffa KR (1988) Radiodensitometric-dendroclimatological conifer chronologies from Lapland (Scandinavia) and the Alps (Switzerland). Boreas 17:559-566

Seppä H, Birks HJB (2002) Holocene climate reconstructions from the Fennoscandian tree-line area based on pollen data from Toskaljavri. Quatern Res 57:191-199

Shemesh A, Rosqvist G, Rietti-Shati M, Rubensdotter L, Bigler C, Yam R, Karlén W (2001) Holocene climatic change in Swedish Lapland inferred from an oxygen-isotope record of lacustrine biogenic silica. Holocene 11:447-454

Sheppard PR (1991) Identifying low-frequency tree-ring variation. Tree Ring Bull 51:29-38

Sirén G (1961) Skogsgränstallen som indikator för klimatfluktuationerna i norra Fennoscandien under historisk tid. Communicationes Instituti Forestalis Fenniae 54:1-66

Svenonius E (1910) Die Gletscher Schwedens im Jahre 1908, Rep. No. Ca 5. Sveriges Geologiska Undersökning

Tranquillini W (1979) Physiological ecology of the alpine timberline. Springer, Berlin

Vaganov EA, Hughes MK, Kirdyanov AV, Schweingruber FH, Silkin PP (1999) Influence of snowfall and melt timing on tree growth in subarctic Eurasia. Nature 400:149-151 
von Storch H, Zorita E, Jones JM, Dimitriev Y, Gonzalez-Rouco F, Tett SFB (2004) Reconstructing past climate from noisy data. Science 306:679-682

Warren WG (1980) On removing the growth trend from dendrochronological data. Tree Ring Bull 40:35-44

Weckström J, Korhola A, Erästö P, Holmström L (2006) Temperature patters over past eight centuries in Northern Fennoscandia inferred from sedimentary diatoms. Quatern Res 66:78-86

Wigley TML, Briffa KR, Jones PD (1984) On the average value of correlated time series, with applications in dendroclimatology and hydrometeorology. J Clim Appl Meteorol 23:201-213
Wilmking M, Juday GP, Barber VA, Zald HSJ (2004) Recent climate warming forces contrasting growth responses of white spruce at treeline in Alaska through temperature thresholds. Glob Change Biol 10:1724-1736

Wilmking M, D’Arrigo R, Jacoby GC, Juday GP (2005) Increased temperature sensitivity and divergent growth trends in circumpolar boreal forests. Geophys Res Lett 32:L15715

Worsley P, Alexander MJ (1976) Glacier and environmental changes-Neoglacial data from the outermost moraine ridges at Engabreen, northern Norway. Geogr Ann 58A:55-69 